\title{
$N$-(2-Pyridyl)-5-chlorosalicylideneimine Schiff Base and its Tellurium(IV) Complexes: Synthesis, Characterization and In Vitro Biological Activities
}

\author{
ANJU MALIK, GOBIND GOYAT, VIKAS, \\ MANISH KUMAR, K.K.VERMA and SAPANA GARG ${ }^{*}$ \\ Department of Chemistry, Maharshi Dayanand University, Rohtak-124001, India \\ sapanagarg1511@gmail.com
}

Received 1 December 2017 / Accepted 14 December 2017

\begin{abstract}
Tridentate Schiff base (2-APY- $\{5-\mathrm{ClSalH}\})$ has been prepared by the condensation of 5-chlorosalicylaldehyde with 2-aminopyridine and further new tellurium(IV) complexes i.e. $\left[\mathrm{TeCl}_{3}(2-\mathrm{APY}-\{5-\mathrm{ClSal}\})\right],\left[\mathrm{RTeCl}_{2}(2-\mathrm{APY}-\{5-\mathrm{ClSal}\})\right]$ and $\left[\mathrm{R}_{2} \mathrm{TeCl}(2-\mathrm{APY}-\{5-\mathrm{ClSal}\})\right]:$ where $\mathrm{R}=p$-methoxyphenyl, $p$-hydroxyphenyl, 3-methyl-4-hydroxyphenyl, of this Schiff base have been synthesized. The characterization of ligand and complexes was carried out by elemental analyses, conductivity measurements, FT-IR and ${ }^{1} \mathrm{H}$ NMR spectral data. The Schiff base ligand as well as their some tellurium(IV) complexes were tested for antimicrobial activities in vitro against Grampositive bacteria i.e. Staphylococcus aureus and Streptococcus pyogenes and Gram-negative bacteria i.e. Pseudomonas aeruginosa and Escherichia coli and fungi i.e. Candida albicans, Aspergillus niger and Aspergillus clavatus by broth dilution method.
\end{abstract}

Keywords: 5-Chlorosalicylaldehyde, Tridentate, Schiff base, 2-Aminopyridine, Antimicrobial activities

\section{Introduction}

A Schiff base is the nitrogen analogue of aldehyde in which the $\mathrm{C}=\mathrm{O}$ group is replaced by a $\mathrm{C}=\mathrm{N}$ group $^{1}$. They also exhibit a variety of biological activities but with substituted salicylaldehyde compounds possesses higher activities ${ }^{2}$. This has led to concentrate deep research on this class of compounds $^{3}$ and their metal complexes ${ }^{4,5}$. Similarly, the presence of hetro-atoms in the Schiff bases enhances activity ${ }^{6}$, particularly when the group such as $-\mathrm{OH} /-\mathrm{SH}$ are near to azomethine group, resulting in the formation of five or six membered ring complexes ${ }^{7-12}$. Schiff bases are reported to have biological activities like antibacterial ${ }^{13-21}$, antifungal ${ }^{13,15-18,22}$, antitumor $^{16,23,24}$, antiviral ${ }^{25-27}$, anti-HIV ${ }^{28}$, herbicidal ${ }^{29}$ and anti influenza A virus ${ }^{30}$ activities.

Tellurium(IV) chloride is also known to form adducts with amides ${ }^{31,32}$ and thiourea ${ }^{33}$, thus reflecting its acceptor behaviour ${ }^{7,834-41}$. The present study has thrown light on the chelating behaviour of Schiff base derived from 5-chlorosalicylaldehyde and 2-aminopyridine towards organyltellurium(IV) chlorides which are known, ${ }^{7,8,34-58}$ to act as Lewis acids. These complexes have been examined for their antimicrobial activity against different strains of bacteria and fungi. 


\section{Experimental}

All chemicals used were of analytical reagent grade. All preparations were carried out under an atmosphere of dry $\mathrm{N}_{2}$ atmosphere. The solvents were purified by standard method ${ }^{59,60}$ before use. The purity of compounds was checked by TLC using Silica gel-G (Merck). Melting points were determined in open capillary tube and are uncorrected.

Carbon, hydrogen and nitrogen analyses were obtained microanalytically from SAIF, Panjab University Chandigarh on a ThermoFinnigan CHNS analyser. Conductance studies were performed under dry condition in DMSO at $25 \pm 2{ }^{\circ} \mathrm{C}$ with a dip type conductivity cell on a microprocessor based conductivity bridge type MICROSIL.

Infrared spectra (4000-40 $\mathrm{cm}^{-1}$ ) were recorded in $\mathrm{KBr}$ and polyethylene pellets for MidIR and Far-IR respectively, on a FT-Infra-Red spectrometer Model Nicolet IS50 (Thermo Scientific). Proton NMR Spectra were recorded in DMSO- $\mathrm{d}_{6}$ using tetramethylsilane as an internal reference on BRUKER AVANCE II 400 NMR spectrometer.

\section{Preparation of organyltellurium(IV) trichlorides and diorganyltellurium(IV)} dichlorides

4-Methoxyphenyltellurium(IV) trichloride $^{61,62}, \quad$ bis( $p$-methoxyphenyl)tellurium(IV) dichloride $^{62,63}$, 4-hydroxyphenyltellurium(IV) trichloride $^{64}$, bis(p-hydroxyphenyl) tellurium(IV) dichloride ${ }^{64}$, 3-methyl-4-hydroxyphenyltellurium(IV) trichloride $^{65}$ and bis(3-methyl-4-hydroxyphenyl)tellurium(IV) dichloride ${ }^{65}$ were prepared by the reactions of tellurium tetrachloride (Aldrich) with corresponding arenes i.e. anisole, phenol, $o$-cresol respectively, by the methods reported in the literature ${ }^{61-65}$.

Preparation of 5-chlorosalicylaldehyde-2-aminopyridine (2-APY-\{5-ClSalH $\})$ Schiff base

The Schiff base was prepared by mixing equimolecular quantity of 5chlorosalicylaldehyde ( 0.08 mole, $12.53 \mathrm{~g})$ and 2-aminopyridine $(0.08$ mole, $7.52 \mathrm{~g})$ in $25 \mathrm{~mL}$ methanol in a round bottomed flask equipped with a condenser ${ }^{66}$. The reaction mixture was refluxed on water bath for 4 hours. After cooling, the precipitated Schiff base was collected by filtration and recrystallized from methanol. The orange shiny crystalline product was dried in a desiccator over anhydrous $\mathrm{CaCl}_{2}$ and kept over $\mathrm{P}_{4} \mathrm{O}_{10}$. Yield $=88 \%$, m.pt. $=123-125^{\circ} \mathrm{C}$.

\section{Preparation of complexes}

Tellurium tetrachloride, organyltellurium(IV) trichlorides and diorganyltellurium(IV) dichlorides, when reacted with Schiff base (2-APY- $\{5-\mathrm{ClSalH}\})$, form solid complexes as described below:

$\left[\mathrm{TeCl}_{3}(2-\mathrm{APY}-\{5-\mathrm{ClSal}\})\right], \quad\left[\mathrm{RTeCl} \mathrm{C}_{2}(2-\mathrm{APY}-\{5-\mathrm{ClSal}\})\right] \quad$ and $\quad\left[\mathrm{R}_{2} \mathrm{TeCl}(2-\mathrm{APY}-\{5-\right.$ ClSal\})]

The solid complexes were prepared by addition of $5 \mathrm{mmol}$ tellurium(IV) derivatives in about $25 \mathrm{~mL}$ anhydrous methanol to a hot solution of $5 \mathrm{mmol}$ Schiff base (2-APY-\{5$\mathrm{ClSalH}\}$ ) in about $25 \mathrm{~mL}$ methanol with continuous stirring. The reaction mixture was refluxed on steam bath for 4 hours. The excess solvent was distilled off to obtain the desired products which were recrystallized from dry methanol. The coloured complexes crystallized out, which were filtered, washed with dry methanol and dried in a vacuum desiccator over $\mathrm{P}_{4} \mathrm{O}_{10}$. 


\section{Results and Discussion}

Anisole ${ }^{61-63}$, phenol $^{64}$ and $o$-cresol ${ }^{65}$ (R-H) undergo Friedel-Crafts type condensation reaction when reacted with tellurium tetrachloride in boiling organic solvents to form organyltellurium(IV) trichlorides and diorganyltellurium(IV) dichlorides. This reaction involves the electrophilic substitution of the aromatic ring by a trichlorotellurium group at a position para to the methoxy / hydroxyl groups.

$$
\begin{aligned}
\mathrm{R}-\mathrm{H} & +\mathrm{TeCl}_{4} \longrightarrow \mathrm{RTeCl}_{3}+\mathrm{HCl} \\
2 \mathrm{R}-\mathrm{H}+\mathrm{TeCl}_{4} & \longrightarrow \mathrm{R}_{2} \mathrm{TeCl}_{2}+2 \mathrm{HCl}
\end{aligned}
$$

Preparation of Schiff Base by the reaction of 5-chlorosalicylaldehyde with 2-aminopyridine are represented in the following equation.<smiles>O=Cc1cc(Cl)ccc1O</smiles>

5-Chlorosalicylaldehyde<smiles>Nc1cccc(C=CC(=O)O)n1</smiles>

(2-APY- $\{5-\mathrm{ClSalH}\})$

Schiff Base reacts with tellurium(IV) chloride, organyltellurium(IV) trichlorides and diorganyltellurium(IV) dichlorides in 1:1 molar ratio to yield the corresponding organyltellurium(IV) complexes.

$$
\begin{aligned}
\mathrm{TeCl}_{4}+(2-\mathrm{APY}-\{5-\mathrm{CISalH}\}) & \longrightarrow \mathrm{TeCl}_{3}(2-\mathrm{APY}-\{5-\mathrm{CISal}\}) \\
\mathrm{RTeCl}_{3}+(2-\mathrm{APY}-\{5-\mathrm{CISalH}\}) & \longrightarrow \mathrm{RTeCl}_{2}(2-\mathrm{APY}-\{5-\mathrm{CISal}\}) \\
\mathrm{R}_{2} \mathrm{TeCl}_{2}+(2-\mathrm{APY}-\{5-\mathrm{CISalH}\}) & \longrightarrow \mathrm{R}_{2} \mathrm{TeCl}(2-\mathrm{APY}-\{5-\mathrm{CISal}\})
\end{aligned}
$$

All the tellurium(IV) complexes are colored, crystalline solids, stable at room temperature and non-hygroscopic in nature. They are insoluble in non polar and less polar organic solvents, but are soluble in polar donor solvents like DMF, DMSO etc. The analytical data along with their physical properties are presented in Table 1.

\section{Conductance studies}

The molar conductance $\left(\Lambda_{\mathrm{M}}\right)$ data for organyltellurium(IV) Schiff base complexes in DMSO are compiled in Table 1 . The $\Lambda_{\mathrm{M}}$ values at $c a \cdot 10^{-3} \mathrm{M}$ of complexes lies in the range 19.45$53.06 \mathrm{~S} \mathrm{~cm}^{2} \mathrm{~mol}^{-1}$ which predict the non-electrolyte to $1: 1$ weak electrolyte type behavior ${ }^{67,68}$ of these Schiff base complexes in DMSO, probably due to ionization into $\mathrm{TeCl}_{2}(2-\mathrm{APY}-\{5$ $\mathrm{ClSal}\})^{+} / \mathrm{RTeCl}(2-\mathrm{APY}-\{5-\mathrm{ClSal}\})^{+} / \mathrm{R}_{2} \mathrm{Te}(2-\mathrm{APY}-\{5-\mathrm{ClSal}\})^{+}$and $\mathrm{Cl}^{-}$in DMSO. The higher $\Lambda_{\mathrm{M}}$ values for some complexes may be due to steric factors and donor behavior of DMSO to result in probable dissociation into solvated cation and 2-APY- $\{5-\mathrm{ClSal}\}^{-}$along with $\mathrm{Cl}^{-}$in DMSO. This conductance behavior of tellurium(IV) Schiff base complexes is different from those of transition metal complexes ${ }^{69}$ which are reported to be non-electrolytes.

\section{Infrared spectra}

The IR spectra for our studied complexes and free ligand listed in Table 2 give information about the coordination of the ligand to metal. The IR spectrum of the ligand indicate that the $v_{(\mathrm{C}=\mathrm{N})}$ band $\mathrm{d}^{31,38,41,66,70}$ of the ligand at $1613 \mathrm{~cm}^{-1}$ is due to the azomethine linkage which were shifted towards lower frequency ${ }^{22,38,41,66,70-72}$ indicating that the ligand coordinate to tellurium metal ions via the azomethine nitrogen ${ }^{73,74}$. 
Table 1. Analytical data, molar conductance and physical properties for Schiff base (2-APY- $\{5-\mathrm{ClSalH}\})$ complexes of tellurium(IV)

\begin{tabular}{|c|c|c|c|c|c|c|c|c|c|c|}
\hline \multirow{2}{*}{$\begin{array}{l}\text { Compd. } \\
\text { No. }\end{array}$} & \multirow{2}{*}{$\begin{array}{l}\text { Complex } \\
\text { (R) }\end{array}$} & \multirow{2}{*}{$\begin{array}{l}\text { Empirical formula } \\
\text { (Formula Wt.) }\end{array}$} & \multirow{2}{*}{$\begin{array}{c}\text { Colour } \\
\text { (Yield), } \\
\%\end{array}$} & \multirow{2}{*}{$\begin{array}{l}\text { M. Pt. } \\
{ }^{\circ} \mathrm{C} \\
\text { dec. }\end{array}$} & \multicolumn{5}{|c|}{ Analyses $\%$ found (Calculated) } & \multirow{2}{*}{$\begin{array}{c}\Lambda_{\mathrm{M}} \text { at } c a \cdot 10^{-3} \mathrm{M} \\
\mathrm{S} \mathrm{cm}^{2} \mathrm{~mol}^{-1} \\
\text { in DMSO }\end{array}$} \\
\hline & & & & & $\mathbf{C}$ & $\mathbf{H}$ & $\mathbf{N}$ & Te & $\mathrm{Cl}$ & \\
\hline $\begin{array}{c}\text { Schiff } \\
\text { Base }\end{array}$ & $\begin{array}{c}\text { (2-APY- }\{5- \\
\text { ClSalH }\}) \\
\end{array}$ & $\begin{array}{c}\mathrm{C}_{12} \mathrm{H}_{9} \mathrm{ClN}_{2} \mathrm{O} \\
(232.64) \\
\end{array}$ & $\begin{array}{c}\text { Orange } \\
(88)\end{array}$ & $123-125$ & $\begin{array}{c}61.74 \\
(61.95) \\
\end{array}$ & $\begin{array}{c}3.95 \\
(3.87) \\
\end{array}$ & $\begin{array}{c}11.92 \\
(12.04) \\
\end{array}$ & - & $\begin{array}{c}15.14 \\
(15.26) \\
\end{array}$ & 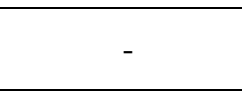 \\
\hline $\mathbf{I}$ & $\begin{array}{c}\mathrm{TeCl}_{3}(2-\mathrm{APY}-\{5- \\
\mathrm{ClSal}\}) \\
\end{array}$ & $\begin{array}{c}\mathrm{C}_{12} \mathrm{H}_{8} \mathrm{Cl}_{4} \mathrm{~N}_{2} \mathrm{OTe} \\
(465.74)\end{array}$ & $\begin{array}{l}\text { Yellowis } \\
\text { h green } \\
(74)\end{array}$ & $118-120$ & $\begin{array}{c}30.72 \\
(30.94)\end{array}$ & $\begin{array}{c}1.84 \\
(1.72)\end{array}$ & $\begin{array}{c}5.89 \\
(6.02)\end{array}$ & $\begin{array}{c}27.32 \\
(27.40)\end{array}$ & $\begin{array}{c}30.35 \\
(30.49)\end{array}$ & 23.51 \\
\hline II & $\begin{array}{c}\mathrm{RTeCl}_{2}(2-\mathrm{APY}- \\
\{5-\mathrm{ClSal}\}) \\
\text { (p-methoxyphenyl) }\end{array}$ & $\begin{array}{c}\mathrm{C}_{19} \mathrm{H}_{15} \mathrm{Cl}_{3} \mathrm{~N}_{2} \mathrm{O}_{2} \mathrm{Te} \\
(537.31)\end{array}$ & $\begin{array}{l}\text { Cream } \\
(71)\end{array}$ & $154-156$ & $\begin{array}{c}42.24 \\
(42.47)\end{array}$ & $\begin{array}{l}2.85 \\
(2.79)\end{array}$ & $\begin{array}{c}5.13 \\
(5.21)\end{array}$ & $\begin{array}{c}23.62 \\
(23.75)\end{array}$ & $\begin{array}{c}19.71 \\
(19.82)\end{array}$ & 32.11 \\
\hline III & $\begin{array}{c}\mathrm{RTeCl}_{2}(2-\mathrm{APY}- \\
\{5-\mathrm{ClSal}\}) \\
\text { (p-hydroxyphenyl) }\end{array}$ & $\begin{array}{c}\mathrm{C}_{18} \mathrm{H}_{13} \mathrm{Cl}_{3} \mathrm{~N}_{2} \mathrm{O}_{2} \mathrm{Te} \\
(523.30)\end{array}$ & $\begin{array}{l}\text { Brown } \\
(78)\end{array}$ & $189-191$ & $\begin{array}{c}41.15 \\
(41.31)\end{array}$ & $\begin{array}{c}2.56 \\
(2.48)\end{array}$ & $\begin{array}{c}5.27 \\
(5.35)\end{array}$ & $\begin{array}{l}24.46 \\
(24.38)\end{array}$ & $\begin{array}{c}20.22 \\
(20.35)\end{array}$ & 19.45 \\
\hline IV & $\begin{array}{c}\mathrm{RTeCl}_{2}(2-\mathrm{APY}- \\
\{5-\mathrm{ClSal}\}) \\
\text { (3-methyl-4- } \\
\text { hydroxyphenyl) }\end{array}$ & $\begin{array}{c}\mathrm{C}_{19} \mathrm{H}_{15} \mathrm{Cl}_{3} \mathrm{~N}_{2} \mathrm{O}_{2} \mathrm{Te} \\
(537.31)\end{array}$ & $\begin{array}{l}\text { Light } \\
\text { Brown } \\
(81)\end{array}$ & $171-173$ & $\begin{array}{c}42.31 \\
(42.47)\end{array}$ & $\begin{array}{l}2.87 \\
(2.79)\end{array}$ & $\begin{array}{l}5.08 \\
(5.21)\end{array}$ & $\begin{array}{c}23.89 \\
(23.75)\end{array}$ & $\begin{array}{l}19.68 \\
(19.82)\end{array}$ & 27.09 \\
\hline $\mathbf{V}$ & $\begin{array}{c}\mathrm{R}_{2} \mathrm{TeCl}(2-\mathrm{APY}- \\
\{5-\mathrm{ClSal}\}) \\
\text { (p-methoxyphenyl) }\end{array}$ & $\begin{array}{c}\mathrm{C}_{26} \mathrm{H}_{22} \mathrm{Cl}_{2} \mathrm{~N}_{2} \mathrm{O}_{3} \mathrm{Te} \\
(608.88)\end{array}$ & $\begin{array}{l}\text { Light } \\
\text { Orange } \\
(69)\end{array}$ & $220-222$ & $\begin{array}{c}51.04 \\
(51.28)\end{array}$ & $\begin{array}{c}3.69 \\
(3.61)\end{array}$ & $\begin{array}{c}4.47 \\
(4.60)\end{array}$ & $\begin{array}{c}20.84 \\
(20.96)\end{array}$ & $\begin{array}{c}11.54 \\
(11.66)\end{array}$ & 46.87 \\
\hline VI & $\begin{array}{c}\mathrm{R}_{2} \mathrm{TeCl}(2-\mathrm{APY}- \\
\{5-\mathrm{ClSal}\}) \\
\text { (p-hydroxyphenyl) }\end{array}$ & $\begin{array}{c}\mathrm{C}_{24} \mathrm{H}_{18} \mathrm{Cl}_{2} \mathrm{~N}_{2} \mathrm{O}_{3} \mathrm{Te} \\
(580.86)\end{array}$ & $\begin{array}{l}\text { Light } \\
\text { Brown } \\
(79)\end{array}$ & $173-175$ & $\begin{array}{c}49.47 \\
(49.62)\end{array}$ & $\begin{array}{c}3.22 \\
(3.10)\end{array}$ & $\begin{array}{c}4.71 \\
(4.82)\end{array}$ & $\begin{array}{l}21.82 \\
(21.97)\end{array}$ & $\begin{array}{c}12.05 \\
(12.22)\end{array}$ & 53.06 \\
\hline VII & $\begin{array}{c}\mathrm{R}_{2} \mathrm{TeCl}(2-\mathrm{APY}- \\
\{5-\mathrm{ClSal}\}) \\
\text { (3-methyl-4- } \\
\text { hydroxyphenyl) }\end{array}$ & $\begin{array}{c}\mathrm{C}_{26} \mathrm{H}_{22} \mathrm{Cl}_{2} \mathrm{~N}_{2} \mathrm{O}_{3} \mathrm{Te} \\
(608.88)\end{array}$ & $\begin{array}{l}\text { Light } \\
\text { Grey } \\
(85)\end{array}$ & $163-165$ & $\begin{array}{c}51.09 \\
(51.28)\end{array}$ & $\begin{array}{c}3.72 \\
(3.61)\end{array}$ & $\begin{array}{c}4.52 \\
(4.60)\end{array}$ & $\begin{array}{l}21.08 \\
(20.96)\end{array}$ & $\begin{array}{c}11.49 \\
(11.66)\end{array}$ & 50.21 \\
\hline
\end{tabular}


Table 2. Important IR data $\left(\mathrm{cm}^{-1}\right)$ of the Schiff base (2-APY- $\left.\{5-\mathrm{ClSalH}\}\right)$ and complexes

\begin{tabular}{cccccc}
\hline $\begin{array}{c}\text { Compound } \\
\text { No. }\end{array}$ & $\begin{array}{c}\text { (Phenolic) } \\
v_{(\mathrm{OH})}\end{array}$ & $\begin{array}{c}\text { (Azomethine) } \\
\mathrm{v}_{(\mathrm{C}=\mathrm{N})}\end{array}$ & $\begin{array}{c}\text { (Pyridine) } \\
\mathrm{v}_{(\mathrm{C}-\mathrm{N}-\mathrm{C})}\end{array}$ & $v_{(\mathrm{Te}-\mathrm{O})}$ & $v_{(\mathrm{Te}-\mathrm{N})}$ \\
\hline $\begin{array}{c}\text { (2-APY- } \\
\text { \{5-ClSalH }\})\end{array}$ & $3085 \mathrm{~b}$ & $1613 \mathrm{~s}$ & $1486 \mathrm{~s}$ & - & - \\
I & - & $1568 \mathrm{~m}$ & $1542 \mathrm{~s}$ & $293 \mathrm{~s}$ & $409 \mathrm{~s}$ \\
II & - & $1581 \mathrm{~s}$ & $1542 \mathrm{mb}$ & $293 \mathrm{~s}$ & $420 \mathrm{~s}$ \\
III & - & $1580 \mathrm{~m}$ & $1541 \mathrm{~m}$ & $290 \mathrm{~s}$ & $419 \mathrm{~s}$ \\
IV & - & $1586 \mathrm{~s}$ & $1543 \mathrm{~s}$ & $292 \mathrm{~s}$ & $416 \mathrm{~s}$ \\
V & - & $1569 \mathrm{~m}$ & $1544 \mathrm{~m}$ & $292 \mathrm{~s}$ & $420 \mathrm{~s}$ \\
VI & - & $1576 \mathrm{~s}$ & $1544 \mathrm{~m}$ & $290 \mathrm{~s}$ & $419 \mathrm{~s}$ \\
VII & - & $1576 \mathrm{~s}$ & $1544 \mathrm{~s}$ & $289 \mathrm{~s}$ & $419 \mathrm{~s}$ \\
\hline
\end{tabular}

$s=$ strong, $m=$ medium, $b=$ broad

The absence of peak due to the phenolic $-\mathrm{OH}$ group at $3085 \mathrm{~cm}^{-1}$ suggest the coordination of the ligand to the metal via deprotonation. Schiff base coordination through pyridine nitrogen affecting the $v_{(\mathrm{C}-\mathrm{N}-\mathrm{C})}$ band, therefore the frequency in free ligand at $1486 \mathrm{~cm}^{-1}$ was moved to a higher value and appears in the region $1541-1544 \mathrm{~cm}^{-1}$ in the spectrum of complexes.

The new strong bands in the spectra of complexes appear in the region $289-293 \mathrm{~cm}^{-1}$ and $409-420 \mathrm{~cm}^{-1}$ are ascribed to region might be due to $\mathrm{v}_{(\mathrm{Te}-\mathrm{O})}^{38,41,71,72,75,76}$ and $\mathrm{v}_{(\mathrm{Te}-\mathrm{N})}{ }^{77}$ stretching and confirms that the phenolic oxygen, azomethine and pyridine nitrogen atoms are the coordination sites of the tridentate ligand.

Thus the IR data infers that in studied complexes each tellurium atom is in octahedral environment is coordinated by tridentate monobasic $O N N$ Schiff base, chlorides and organyl groups (in the different numbers).

\section{${ }^{1}$ H NMR spectra}

Further, evidence for the coordination mode of the ligand is obtained by the ${ }^{1} \mathrm{H}$ NMR studies. The ${ }^{1} \mathrm{H}$ NMR spectra data was recorded in DMSO- $\mathrm{d}_{6}$ and presented in Table 3.

Table 3. ${ }^{1} \mathrm{H}$ NMR spectral data of Schiff base (2-APY- $\left.\{5-\mathrm{ClSalH}\}\right)$ and complexes

\begin{tabular}{|c|c|c|c|c|c|}
\hline $\begin{array}{l}\text { Compound } \\
\text { No }\end{array}$ & $\begin{array}{l}\text { (Phenolic) } \\
\text {-OH } \delta \mathrm{ppm}\end{array}$ & $\begin{array}{l}\text { (Azomethine) } \\
-\mathrm{HC}=\mathrm{N} \delta \mathrm{ppm}\end{array}$ & $\begin{array}{c}\text { (Ar rings protons) } \\
\delta \mathrm{ppm}\end{array}$ & $\begin{array}{c}-\mathrm{CH}_{3} /-\mathrm{OCH}_{3}{ }^{*} \\
\delta \mathrm{ppm}\end{array}$ & $\begin{array}{c}-\mathrm{OH} \text { of } \mathrm{Te} / \mathrm{R}_{2} \mathrm{Te} \\
\delta \mathrm{ppm}\end{array}$ \\
\hline $\begin{array}{c}(2-\mathrm{APY}- \\
\{5-\mathrm{ClSalH}\})\end{array}$ & $\begin{array}{l}13.460 \\
(\mathrm{~s}, 1 \mathrm{H}) \\
\end{array}$ & $9.392(\mathrm{~s}, 1 \mathrm{H})$ & $\begin{array}{c}6.970-8.527 \\
(\mathrm{~cm}, 7 \mathrm{H})\end{array}$ & - & - \\
\hline I & - & $\begin{array}{l}10.254 \\
(\mathrm{~s}, 1 \mathrm{H})\end{array}$ & $\begin{array}{c}6.955-8.012 \\
(\mathrm{~cm}, 7 \mathrm{H})\end{array}$ & - & - \\
\hline III & - & $10.262(\mathrm{~s}, 1 \mathrm{H})$ & $\begin{array}{c}7.596-8.651 \\
(\mathrm{~cm}, 11 \mathrm{H})\end{array}$ & - & $9.025(\mathrm{~s}, 1 \mathrm{H})$ \\
\hline $\mathbf{V}$ & - & $10.265(\mathrm{~s}, 1 \mathrm{H})$ & $\begin{array}{c}6.840-8.237 \\
(\mathrm{~cm}, 15 \mathrm{H})\end{array}$ & $\begin{array}{l}3.368 \\
\left(\mathrm{~s}, 6 \mathrm{H}^{*}\right)\end{array}$ & - \\
\hline VI & - & $10.271(\mathrm{~s}, 1 \mathrm{H})$ & $\begin{array}{l}7.587-8.024 \\
(\mathrm{~cm}, 15 \mathrm{H})\end{array}$ & - & $8.989(\mathrm{~s}, 2 \mathrm{H})$ \\
\hline VII & - & $10.265(\mathrm{~s}, 1 \mathrm{H})$ & $\begin{array}{c}6.849-8.101 \\
(\mathrm{~cm}, 13 \mathrm{H})\end{array}$ & $\begin{array}{l}2.509 \\
(\mathrm{~s}, 6 \mathrm{H})\end{array}$ & $9.014(\mathrm{~s}, 2 \mathrm{H})$ \\
\hline
\end{tabular}

$s=$ singlet, $\mathrm{cm}=$ complex multiplet. Spectra of compound numbers II and IV are not well resolved due to poor solubility 
The absence of a singlet in high frequency region $(\delta 13.460 \mathrm{ppm})$, which typically corresponds to phenolic hydrogen indicates that $\mathrm{N}$-2-pyridyl-5-chlorosalicylideneimine binds tellurium by deprotonated phenolic oxygen. The singlet that appears at $\delta 9.392 \mathrm{ppm}$ is ascribed to azomethine hydrogen, which is less shielded after coordination through azomethine nitrogen ${ }^{38,41,50,51,70,78}$ and appear in the downfield region 10.254-10.271 $\delta \mathrm{ppm}$. The complex multiplets found in the spectrum of complexes in the $\delta 6.840-8.651 \mathrm{ppm}$ region corresponds to coupled hydrogen atoms of aromatic rings.

The ${ }^{1} \mathrm{H}$ NMR spectroscopic data are in good agreement with others experimental results and strongly support the proposed structure of the complexes. On the basis of these studies, the proposed structures for the complexes are as below (Figure 1).<smiles>Oc1ccc(Cl)cc1/C=N/c1ccccn1</smiles>

(2-APY- $\{5-\mathrm{ClSalH}\})$

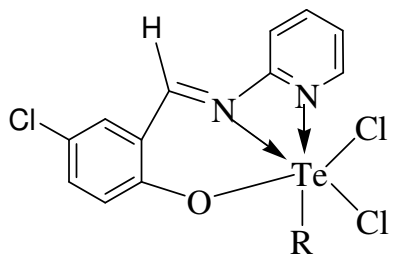

$\mathrm{RTeCl}_{2}(2-\mathrm{APY}-\{5-\mathrm{ClSal}\})$<smiles>Clc1ccc2c(c1)O[Te](Cl)(Cl)N(c1ccccn1)C2</smiles>

$\mathrm{TeCl}_{3}(2-\mathrm{APY}-\{5-\mathrm{ClSal}\})$<smiles></smiles>

$\mathrm{R}_{2} \mathrm{TeCl}(2-\mathrm{APY}-\{5-\mathrm{ClSal}\})$

Figure 1. Proposed structures of Schiff base (2-APY-\{5-ClSalH $\}$ ) and tellurium(IV) complexes

\section{Biological studies}

In vitro antibacterial activity of the Schiff base (2-APY- $\{5-\mathrm{ClSalH}\})$ and their tellurium(IV) complexes were evaluated $^{79}$ against two Gram-positive bacteria (S. aureus MTCC 96 and $S$. pyogenes MTCC 442), two Gram-negative bacteria ( $P$. aeruginosa MTCC 1688 and E. coli MTCC 443) and antifungal activity against three fungal strains $C$. albicans MTCC 227, A. niger MTCC 282 and A. clavatus MTCC 1323.

The factors that govern antibacterial activities are strongly dependent on the central metal ion and the coordination numbers and also due to the presence of nitrogen and sulfur donor groups ${ }^{80-82}$.

Comparative study of Schiff base and tellurium(IV) complexes indicates that the complexes show higher antibacterial activity than antifungal activity. Schiff base and complex no. III and VI i.e. [RTeCl $2(2-\mathrm{APY}-\{5-\mathrm{ClSal}\})]$ and $\left[\mathrm{R}_{2} \mathrm{TeCl}(2-\mathrm{APY}-\{5-\mathrm{ClSal}\})\right]$ : where $\mathrm{R}=p$-hydroxyphenyl respectively, show substantial activity against two bacterial strains ( $P$. aeruginosa and $E$. coli) and even comparable to standard drug ampicillin. The data is given in Table 4. 
Table 4. Minimum inhibitory concentration MIC $(\mu \mathrm{g} / \mathrm{mL})$ of Schiff base (2-APY- $\{5-$ $\mathrm{ClSalH}\}$ ) and complexes

\begin{tabular}{cccccccc}
\hline & \multicolumn{4}{c}{ Bacterial Strain } & \multicolumn{3}{c}{ Fungal Strain } \\
\cline { 2 - 8 } Compound & S. & S. & $P$. & $E$. & $C$. & A. & A. \\
Number & aureus & pyogenes & aeruginosa & coli & albicans & niger & clavatus \\
& MTCC & MTCC & MTCC & MTCC & MTCC & MTCC & MTCC \\
& 96 & 442 & 1688 & 443 & 227 & 282 & 1323 \\
\hline (2-APY- & 250 & 250 & 100 & 62.5 & 500 & 1000 & 1000 \\
$\{5-$ ClSalH $\})$ & 500 & 500 & 200 & 200 & $\mathbf{2 5 0}$ & 1000 & 1000 \\
1 & 250 & 250 & 250 & 250 & 1000 & 1000 & 1000 \\
2 & 250 & 250 & $\mathbf{1 0 0}$ & $\mathbf{6 2 . 5}$ & 1000 & 1000 & 1000 \\
3 & 500 & 500 & $\mathbf{1 0 0}$ & $\mathbf{1 2 5}$ & 500 & $\mathbf{5 0 0}$ & $\mathbf{5 0 0}$ \\
6 & Standard Drugs & & & & & \\
& 250 & 100 & 100 & 100 & - & - & - \\
Ampicillin & 50 & 50 & 50 & 50 & - & - & - \\
Chloramphenicol & 50 & - & - & - & 100 & 100 & 100 \\
Nystatin & - & - & - & - & 500 & 100 & 100 \\
Greseofulvin & - & - & & & &
\end{tabular}

\section{Conclusion}

The complexes of tellurium(IV) with Schiff base derived from 5-chlorosalicylaldehyde and 2-aminopyridine have been synthesized and characterized by elemental analyses, conductance measurement, IR and ${ }^{1} \mathrm{H}$ NMR spectral studies. All the spectral studies suggest that the Schiff base is tridentate in nature having $O N N$ donor atoms with distorted octahedral geometry. The complexes have been observed to possess good antimicrobial activity against some bacterial and fungal strains.

\section{Acknowledgement}

The authors are grateful to M. D. University, Rohtak for providing the necessary facilities. One of the authors (AM) is also thankful to HSCST, Haryana for providing a fellowship. We also thank SAIF, Panjab University Chandigarh for providing the CHN analyses, ${ }^{1} \mathrm{H}$ NMR spectral data from CIL, Guru Jambeshwar University of Science and Technology, Hissar and the Microcare Laboratory, Surat, for providing antimicrobial activities.

\section{References}

1. Gupta V, Singh S and Gupta Y K, Res J Chem Sci., 2013, 3(9), 26-29.

2. Prisakar V I, Tsapkov V I, Buracheeva S A, Byrke M S and Gulya A P, Pharm Chem J., 2005, 39(6), 313-315; DOI:10.1007/s11094-005-0142-8

3. Pelttari E, Karhumaki E, Langshaw J, Perakyla H and Elo H, Z Naturforsch, 2007, 62C, 487-497.

4. Chohan Z H, Arif M and Sarfraz M, Appl Organomet Chem., 2007, 21(4), 294-302; DOI:10.1002/aoc. 1200

5. Tsapkov V I, Prisakar V I, Buracheeva S A, Lazakovich D V and Gulya A P, Pharm Chem J., 2008, 42(9), 523-526; DOI:10.1007\%2Fs11094-009-0173-7

6. Shi L, Ge H M, Tan S H, Li H Q, Song Y C, Zhu H L and Tan R X, Eur J Med Chem., 2007, 42(4), 558-564; DOI:10.1016/j.ejmech.2006.11.010

7. Goyat G, Malik A, Garg S and Verma K K, Int J Chem Sci., 2016, 14(3), 1498-1510. 
8. Goyat G, Malik A, Garg S and Verma K K, J Chem Pharm Res., 2016, 8(4), 218-223.

9. Canpolat E and Kaya M, Russ J Coord Chem., 2005, 31(11), 790-794; DOI:10.1007/s11173-005-0170-7

10. Booysena I N, Maikoa S, Akermana M P, Xulua B and Murno O, J Coord Chem., 2013, 66(20), 3673-3685; DOI:10.1080/00958972.2013.849808

11. Barwiolek M, Szlyk E, Surdykowski A and Wojtczak A, Dalton Trans., 2013, 42, 11476-11487; DOI:10.1039/C3DT50213A

12. Fernandez-G J M, Portilla F D R, Garcia B Q, Toscano R A and Salcedo R, J Mol Struct., 2001, 561(1-3), 197-207; DOI:10.1016/S0022-2860(00)00915-7

13. Sridhar S K, Saravanan M and Ramesh A, Eur J Med Chem., 2001, 36(7-8), 615625;DOI:10.1016/S0223-5234(01)01255-7

14. Mladenova R, Ignatova M, Manolova N, Petrova T and Rashkov I, Eur Polym J., 2002, 38(5), 989-999; DOI:10.1016/S0014-3057(01)00260-9

15. Panneerselvem P, Nair R R, Vijayalakshmi G, Subramanian E H and Sridhar S K, Eur J Med Chem., 2005, 40(2), 225-229; DOI:10.1016/j.ejmech.2004.09.003

16. Walsh O M, Meegan M J, Prendergast R M and Nakib T A, Eur J Med Chem., 1996, 31, 989-1000; DOI:10.1016/S0223-5234(97)86178-8

17. Pandeya S N, Sriram D, Nath G and DeClercq E, Eur J Pharm Sci., 1999, 9(1), 2531; DOI:10.1016/S0928-0987(99)00038-X

18. Pandeya S N, Sriram D, Nath G and DeClercq E, Pharm Acta Helv., 1999, 74(1), 11 17; DOI:10.1016/S0031-6865(99)00010-2

19. Panneerselvam P, Rather B A, Reddy D R S and Kumar N R, Eur J Med Chem., 2009, 44(5), 2328-2333; DOI:10.1016/j.ejmech.2008.04.010

20. Rai B K and Kumar A, Orient J Chem., 2013, 29(3), 1187-1191.

21. Singh K, Barwa M S and Tyagi P, Eur J Med Chem., 2006, 41(1), 147-153; DOI:10.1016/j.ejmech.2005.06.006

22. Ramesh R and Maheswaran S, J Inorg Biochem., 2003, 96(4), 457-462; DOI:10.1016/S0162-0134(03)00237-X

23. Liu M C, Lin T S and Sartorelli A C, J Med Chem., 1992, 35(20), 3672-3677; DOI:10.1021/jm00098a012

24. Hodnett E M and Dunn J W, J Med Chem., 1970, 13(4), 768-770;

DOI:10.1021/jm00298a054

25. Kumar K S, Ganguly S, Veerasamy R and De Clercq E, Eur J Med Chem., 2010, 45(11), 5474-5479; DOI:10.1016/j.ejmech.2010.07.058

26. Jarrahpour A, Khalili D, DeClercq E, Salmi C and Brunel J M, Molecules, 2007, 12(8), 1720-1730; DOI:10.3390/12081720

27. Mishra P M, Orient J Chem., 2013, 29(2), 677-683.

28. Vicini P, Geronikaki A, Incerti M, Busonera B, Poni G, Cabras C A and Colla P L, Bioorg Med Chem., 2003, 11(22), 4785-4789; DOI:10.1016/S0968-0896(03)00493-0

29. Holla B S, Rao B S, Shridhara K and Akberali P M, Farmaco, 2000, 55(5), 338-344; DOI:10.1016/S0014-827X(00)00033-1

30. Zhao X, Li C, Zeng $\mathrm{S}$ and $\mathrm{Hu} \mathrm{W}$, Eur J Med Chem., 2011, 46(1), 52-57; DOI:10.1016/j.ejmech.2010.10.010

31. Malhotra K C and Paul K K, Curr Sci., 1969, 38, 266.

32. Peirier M and Vincontini, Anal Acad Brazil Cinene, 1971, 43, 119.

33. Aynsley E E and Campbell W A, J Chem Soc., 1958, 3290-3293; DOI:10.1039/JR9580003290 
34. Goyat G, Garg S and Verma K K, Chem Sci Trans., 2016, 5(2), 479-487; DOI:10.7598/cst2016.1204

35. Goyat G, Garg S and Verma K K, Res J Pharm Biol Chem Sci., 2016, 7(2), 869-877.

36. Goyat G, Malik A, Garg S and Verma K K, Int J Chem Sci., 2016, 14(1), 387-398.

37. Goyat G, Malik A, Garg S and Verma K K, Der Pharma Chemica, 2016, 8(2), 198-203.

38. Malik A, Verma K K and Garg S, Res J Pharm Biol Chem Sci., 2017, 8(6), 190-198.

39. Malik A, Verma K K and Garg S, Chem Sci Trans., 2018, 7(2), 191-200; DOI:10.7598/cst2018.1464

40. Malik A, Goyat G, Vikas, Verma K K and Garg S, Int J Chem Sci., 2018, 16(10), 249.

41. Malik A, Goyat G, Vikas, Verma K K and Garg S, Chem Sci Trans., 2018, 7(2), 329337; DOI:10.7598/cst2018.1480.

42. Wynne K J and Pearson P S, Inorg Chem., 1971, 10(12), 2735-2739; DOI:10.1021/ic50106a022

43. Wynne K J and Pearson P S, J Chem Soc Commun., 1970, 556-557; DOI:10.1039/C2970000556B

44. Wynne K J, Clark A J and Berg M, J Chem Soc Dalton Trans., 1972, 2370-2374; DOI:10.1039/DT9720002370

45. Clark E R, Collet A J and Naik D G, J Chem Soc Dalton Trans., 1973, 1961-1962; DOI:10.1039/DT9730001961

46. Berg M C, Diss Abstr Int., 1972, 33, 2982.

47. Srivastava T N, Singh M and Singh H B, Indian J Chem., 1982, 21A, 307.

48. Srivastava T N, Srivastava R C and Srivastava M, Indian J Chem., 1982, 21A, 539.

49. Srivastava T N, Srivastava R C and Srivastava V K, J Indian Chem Soc., 1983, 60, 891.

50. Garad M V, Polyhedron, 1985, 4, 1353.

51. Verma K K and Reena, Synth React Inorg Met Org Chem., 1999, 29(3), 499-512; DOI:10.1080/00945719909349465

52. Verma K K, Dahiya R and Soni D, Synth React Inorg Met Org Chem., 1999, 29(6), 1033-1052; DOI:10.1080/00945719909349509

53. Verma K K and Dahiya R, Synth React Inorg Met Org Chem., 1999, 29(7), 12991314; DOI:10.1080/00945719909349529

54. Verma K K and Reena, Phosphorus, Sulfur Silicon Related Elements, 1999, 148(1), 227-234; DOI:10.1080/10426509908037013

55. Verma K K and Seema, Int J Chem Sci., 2008, 6(1), 371-380.

56. Srivastava S, Soni D K and Gupta H S, J Indian Chem Soc., 1996, 73, 255.

57. Narwal J K, Chhabra S, Malik R K, Garg S and Verma K K, Oriental J Chem., 2013, 29, 1339-1349.

58. Chhabra S and Verma K K, J Chem Pharm Res., 2010, 2(4), 569-575.

59. Vogel A I, A Text Book of Quantitative Inorganic Analysis Including Elementary Instrumental Analysis, $3^{\text {rd }}$ Edn., Longmans, London, 1975.

60. Weissberger A, Ed., Technique of Organic Chemistry, Vol. 7, $2^{\text {nd }}$ Edn., Interscience Publishers, Inc.: N. Y., 1967.

61. Morgan G T and Kellet R E, J Chem Soc., 1926, 129, 1080-1088; DOI:10.1039/JR9262901080

62. Petragnani $\mathrm{N}$ and Stefani H A, Tellurium in Organic Chemistry, $2^{\text {nd }}$ Edn., Academic Press: London, 2007, 76.

63. Bergman J, Tetrahedron, 1972, 28(12), 3323-3331; DOI:10.1016/S00404020(01)93674-9 
64. Khandelwal B L, Kumar K and Berry F J, Inorg Chim Acta, 1981, 47, 135-137; DOI:10.1016/S0020-1693(00)89319-6

65. Khandelwal B L, Kumar K and Raina K, Synth React Inorg Met Org Chem., 1981, 11(1), 65-78; DOI:10.1080/00945718108059276

66. Abdel-Latif S A, Hassib H B and Issa Y M, Spectrochim Acta(A), 2007, 67(3-4), 950957; DOI:10.1016/j.saa.2006.09.013

67. Geary W J, Coord Chem Rev., 1971, 7(1), 81-122; DOI:10.1016/S00108545(00)80009-0

68. Greenwood N N, Straughan B P and Wilson A E, J Chem Soc A, 1968, 2209-2212; DOI:10.1039/J19680002209

69. Srivastava K P, Singh A and Singh S K, J Appl Chem., 2014, 7(4), 16-23.

70. Dharmaraj N, Trans Metal Chem., 2001, 26(1-2), 105-109; DOI:10.1023/A:1007132408648

71. Verma K K, Varma S and Soni D, Phosphorus, Sulfur Silicon, 2000, 166(1), 231-241; DOI:10.1080/10426500008076544

72. Pant B C, Mc Whinnie W R and Dance N S, J Organmetal Chem., 1973, 63, 305-310; DOI:10.1016/S0022-328X(73)80043-9

73. Kohawole G A and Patel K S, J Chem Soc Dalton Trans., 1981, 1241-1245; DOI:10.1039/DT9810001241

74. Gluvchinsky P, Sinn E and Moeler G M, Spectrochim Acta., 1976, 33(12), 10731077; DOI:10.1016/0584-8539(77)80156-6

75. Srivastava T N and Singh J D, Indian J Chem., 1987, 26A, 260.

76. Chauhan S, Garg S and Verma K K, Chem Sci Trans., 2016, 5(2), 431-441; DOI:10.7598/cst2016.1193

77. Kulkarni Y D, Srivastava S, Abdi S H R and Athar M, Synth React Inorg Met Org Chem., 1985, 15(8), 1043-1059.

78. Khera B, Sharma A K and Kaushik N K, Polyhedron, 1983, 2(11), 1177-1180; DOI:10.1016/S0277-5387(00)84353-3

79. Joshi K R, Rojivadiya A J and Pandya J H, Int J Inorg Chem., 2014, 10, 1155-1162; DOI:10.1155/2014/817412

80. Burkanudeen A R, Azarudeen R S, Ahamed M A R and Gurnule W B, Polymer Bull., 2011, 67(8), 1553-1568; DOI:10.1007/s00289-011-0497-9

81. Refat M S and El-Metwly N M, Spectrochimica Acta A: Mol, Bimol Spectro., 2012, 92, 336-346; DOI:10.1016/j.saa.2012.02.041

82. Sigman D S, Biochemistry, 1990, 29(39), 9097-9105; DOI:10.1021/bi00491a001 